\title{
Cloning, Expression, and Characterization of Male Cynomolgus Monkey Liver Aldehyde Oxidase
}

\author{
Kouichi Hoshino, ${ }^{a}$ Kunio IToH, ${ }^{a}$ Akiko Masubuchi,${ }^{a}$ Mayuko Adachi,${ }^{a}$ Tasuku Asakawa, ${ }^{a}$ \\ Nobuaki Watanabe, ${ }^{b}$ Toshiyuki KosaKA, ${ }^{c}$ and Yorihisa TANAKA* ${ }^{*}, a$ \\ ${ }^{a}$ Department of Drug Metabolism and Pharmacokinetics, Tohoku Pharmaceutical University; 4-4-1 Komatsushima, \\ Aoba-ku, Sendai 981-8558, Japan: ${ }^{b}$ Drug Metabolism and Pharmacokinetics Research Laboratories, Sankyo Co., Ltd.; \\ and ${ }^{c}$ Core Technology Research Laboratories, Sankyo Co., Ltd.; 1-2-58 Hiromachi, Shinagawa-ku, Tokyo 140-8710, \\ Japan. Received January 29, 2007; accepted April 24, 2007; published online May 7, 2007
}

In this study, we investigated the properties of monkey liver aldehyde oxidase directed toward the clarification of species differences. The aldehyde oxidase preparation purified from male cynomolgus monkey liver cytosol showed a major $150 \mathrm{kDa}$ Coomassie brilliant blue (CBB)-stained band together with a minor $130 \mathrm{kDa}$ band using sodium dodecyl sulfate-polyacrylamide gel electrophoresis (SDS-PAGE). Both bands were identified as being aldehyde oxidase by a database search of the MS data obtained with nano-liquid chromatography, quardrupole time of flight, mass spectrometry (nano-LC Q/TOF MS). Based on the sequence coverage, the $130 \mathrm{kDa}$ protein was presumed to be deficient in $20-30 \mathrm{kDa}$ mass from the $N$-terminus. Full male cynomolgus monkey aldehyde oxidase cDNA was cloned and sequenced with the four degenerate primers designed by considering the peptide sequences containing the amino acids specific for monkey aldehyde oxidase. The deduced amino acid sequences had $\mathbf{9 6 \%}$ amino acid identity with those of human enzyme. The aldehyde oxidase expressed in Escherichia coli also exhibited two immunoreactive bands on SDS-PAGE/Western blot analysis. Further, the biphasic pattern was observed for Eadie-Hofstee plots of the $(S)$-enantiospecific 2-oxidation activity of RS-8359 with the expressed and cytosolic monkey liver aldehyde oxidase. The results suggested that two forms of aldehyde oxidase in monkey were the expression products by a single gene. In contrast, the similarly expressed rat aldehyde oxidase showed only one immunoreactive protein and monophasic pattern. The biphasic phenomenon could be caused by the existence of two aldehyde oxidase isoforms or two active sites in a single enzyme or some other reasons. Further studies on the problems of the biphasic pattern and species differences in aldehyde oxidase are needed.

Key words monkey; aldehyde oxidase; cDNA cloning; Escherichia coli expression

Aldehyde oxidase (EC 1.2.3.1, AO), localized in a cytosolic fraction, is a major member of the molybdenum hydroxylase family along with xanthine oxidase. AO plays an important role in the oxidation of endogenous and exogenous $\mathrm{N}$ heterocyclic compounds as well as aliphatic and aromatic aldehydes. ${ }^{1-5)}$ A typical endogenous substrate for $\mathrm{AO}$ is retinal, which is transformed to biologically active retinoic acid. In contrast to an electrophilic attack by microsomal cytochrome P450, AO-catalyzed oxidation involves a nucleophilic attack on an electro-deficient carbon. ${ }^{4,5)}$ This suggests that, in most cases, $\mathrm{AO}$ has complementary substrate specificities with cytochrome P450 in the metabolism of xenobiotics. Further, AO can also catalyze the reduction of several kinds of functional groups including sulfoxides, $N$-oxides, azo dyes, and $N$-hydroxycarbamoyl substituents. ${ }^{5-7)}$ In fact, the atypical antipsychotic drug ziprasidone is a good example of a substance in humans that AO metabolizes to reductive ring-cleaved $S$-methyldihydroziprasidone. ${ }^{8,9)}$

Marked species differences have been well documented for the AO-catalyzed metabolism of a wide range of $N$-heterocyclic drugs. ${ }^{4,5)}$ They include carbazeran, ${ }^{10)}$ brimonidine, ${ }^{11)}$ zaleplon, ${ }^{12)}$ methotrexate, ${ }^{13,14)}$ and famciclovir. ${ }^{15)}$ In addition, large rat strain differences in $\mathrm{AO}$ have been reported for benzaldehyde $^{16)}$ and methotrexate, ${ }^{17)}$ and even the existence of striking variations in $\mathrm{AO}$ activity has been noted in Sprague-Dawley rats ${ }^{18)}$ and Wistar rats. ${ }^{19)}$ We also observed phenomena related to species differences, ${ }^{20,21)}$ rat strain differences, ${ }^{22)}$ and rat individual differences ${ }^{23}$ in the metabolism of RS-8359, which is a selective and reversible MAO-A in- hibitor $^{24-26)}$ and has been developed as an antidepressant. ${ }^{27,28)}$

$\mathrm{AO}$ is a homodimer with a subunit molecular mass of approximately $150 \mathrm{kDa}$. Each monomeric subunit contains a molybdopterin cofactor, a FAD, and two different $2 \mathrm{Fe}-$ $2 \mathrm{~S}$ redox centers. The molecular cloning of AO cDNA has been achieved in mouse, ${ }^{29,30)}$ rat $^{31)}$ rabbit ${ }^{32)}$ bovine, ${ }^{33)}$ and human. ${ }^{34-36)}$ The deduced primary structure of AO proteins has been characterized with regard to consensus sequences for two distinct $2 \mathrm{Fe}-2 \mathrm{~S}$ clusters and five molybdopterin-binding sites. Wright et $\mathrm{al}^{31)}$ indicated that the kinetic differences of $\mathrm{AO}$ activity between male and female rats are due to sensitivity to redox manipulation of AO, which is most likely expressed by a single $\mathrm{AO}$ gene. In human ${ }^{37)}$ and mouse, ${ }^{38)}$ the structures of the $5^{\prime}$-flanking region containing several putative regulatory elements were determined. In spite of the rapid progress in the molecular biology of $\mathrm{AO}$, many published papers still seem to be limited to only the phenomena themselves. Little is known about the molecular mechanism of such pharmacokinetically and pharmacologically important drug-metabolism events as species differences, strain differences, and individual variations.

In this study, we investigated the properties of expressed and liver aldehyde oxidase of male cynomolgus monkeys as one of the topics related to the mechanism of species differences requiring clarification.

\section{MATERIALS AND METHODS}

Chemicals and Reagents RS-8359, its $(S)$-enantiomer, 
and the 2-keto metabolite were supplied by Ube Kosan Co., Ltd. (Yamaguchi, Japan). Hydrocortisone, an internal standard of HPLC analysis, was purchased from Sigma Chemical Co. (St. Louis, MO, U.S.A.). Imidazole was obtained from Wako Pure Chemical Industries, Ltd. (Osaka, Japan). All other reagents were of reagent grade.

Preparation of Liver Cytosolic Fractions Eight-weekold male Crj:Donryu rats were purchased from Charles River Japan (Yokohama, Japan). The animals were housed according to the Guidelines for Animal Experimentation (Tohoku Pharmaceutical University) in cages in rooms with a unidirectional airflow at a controlled temperature $\left(22 \pm 2{ }^{\circ} \mathrm{C}\right)$, relative humidity $(50 \pm 10 \%)$, and 12-h light/dark cycles $(07.00$ 19.00 h). Tap water was available ad libitum and CE2 food (Clea Japan, Tokyo, Japan) was available ad libitum except for overnight fasting before use. The animals were sacrificed by bleeding from the carotid artery under anesthesia and their livers were immediately extracted. The livers of threeto four-year-old male cynomolgus monkeys were kindly provided by Sankyo Co., Ltd. (Tokyo, Japan). The livers were homogenized in three volumes of $10 \mathrm{~mm}$ phosphate buffer (pH 7.4) containing $1.15 \% \mathrm{KCl}$ and $100 \mu \mathrm{M}$ phenylmethanesulfonyl fluoride by a Potter-Elvehjem Teflon homogenizer. The cytosolic fractions were prepared by successive centrifugation at $9000 \boldsymbol{g}$ for $20 \mathrm{~min}$ and then at $105000 \boldsymbol{g}$ for $60 \mathrm{~min}$. Human liver cytoplasmic supernatant was obtained from the HAB (Human and Animal Bridging Research Organization, Tokyo, Japan). The protein concentration was determined with BCA Protein Assay Reagent (Pierce Biotech, Rockford, IL, U.S.A.) with bovine serum albumin as the standard.

Assay of AO-Catalyzed ( $S$ )-Enantiospecific 2-Oxidation Activity of RS-8359 The $(S)$-enantiomer of RS-8359 $(3.1-200 \mu \mathrm{M})$ was incubated at $37^{\circ} \mathrm{C}$ for $30 \mathrm{~min}$ in a reaction mixture $(0.25 \mathrm{ml})$ consisting of $0.2 \mathrm{M}$ phosphate buffer $(\mathrm{pH} 6.0), 1.0 \mathrm{~mm} \mathrm{~K}_{3} \mathrm{Fe}(\mathrm{CN})_{6}, 0.13 \mathrm{~mm}$ ethylenediaminetetraacetic acid (EDTA), and prepared cytosol (about $20 \mathrm{mg} / \mathrm{ml}$, $0.10 \mathrm{ml})$ or expressed enzyme preparation $(5-20 \mu \mathrm{g} / \mathrm{ml}$, $0.1 \mathrm{ml})$. The reaction was stopped by the addition of acetonitrile $(0.50 \mathrm{ml})$ containing $0.2 \mathrm{mg} / \mathrm{ml}$ of hydrocortisone as an internal standard. After that, the mixture was centrifuged at $10000 \mathrm{~g}$ for $5 \mathrm{~min}$. Aliquots $(25 \mu \mathrm{l})$ of the supernatant were analyzed for quantification of the oxidation product by reverse-phase HPLC on a YMC-Pack ODS-A312 column (6.0 mm i.d. $\times 150 \mathrm{~mm}$, YMC Co., Ltd., Kyoto, Japan). A mobile phase was composed of acetonitrile $/ 0.5 \%$ ammonium acetate $(25: 75)$; the flow rate was $1.0 \mathrm{ml} / \mathrm{min}$. The HPLC instrument was a Shimadzu model 6A High Performance Liquid Chromatograph System (Shimadzu Seisakusho Co., Ltd., Kyoto, Japan). The peaks were monitored for absorbance at $315 \mathrm{~nm}$; the peak area was calculated on a Chromatopac CR4A (Shimadzu Seisakusho).

Purification of Male Cynomolgus Monkey Liver Aldehyde The enzyme was purified according to the method described previously. ${ }^{10)}$ Briefly, the cytosolic fraction prepared under the presence of $100 \mu \mathrm{M}$ phenylmethanesulfonyl fluoride was kept at $60{ }^{\circ} \mathrm{C}$ for $10 \mathrm{~min}$ and then the precipitated proteins were separated by centrifugation for $10 \mathrm{~min}$ at $9000 \boldsymbol{g}$. Ammonium sulfate was added to the supernatant to $50 \%$ saturation. The protein precipitates collected by centrifugation were applied to a Benzamidine Sepharose 6B (Amersham Bioscience, Uppsala, Sweden, $3 \times 22 \mathrm{~cm}$ ) fol- lowed by Mono Q HR5/5 column (Amersham Bioscience, $0.5 \times 5.0 \mathrm{~cm}$ ) chromatography.

Preparation of Anti-rat and Anti-monkey Liver Aldehyde Oxidase Antisera Rabbit anti-rat and anti-monkey liver aldehyde oxidase antisera were used in this study. The former antisera were those prepared previously by Sasaki et $\mathrm{al}^{22)}$ For the latter, a necessary amount of monkey aldehyde oxidase was expressed in E. coli and purified. The antibody was prepared at Shibayagi Co., Ltd. (Gunma, Japan). Briefly, the purified enzyme $(1.0 \mathrm{mg}$ protein $/ \mathrm{ml})$ was emulsified with an equal volume of Freund's complete adjuvant (Sigma). Each of two rabbits was immunized with $1 \mathrm{ml}$ of immunogen by intradermal injections every 4 weeks. Four months after the first immunization, blood was obtained by cardiac puncture and antisera were prepared by a conventional method. Pooled antisera were stored at $-80^{\circ} \mathrm{C}$ until use for Western blot analysis.

Gel Electrophoresis and Western Blot Analysis The purified enzymes and liver cytosolic proteins were separated by sodium dodecyl sulfate-polyacrylamide gel electrophoresis (SDS-PAGE), which was performed using PhastGel gradient 4-15 in PhastGel SDS Buffer Strips (Amersham Bioscience). An automatic electrophoresis system, PhastSystem (Amersham Bioscience), was used. Protein bands were stained with Coomassie brilliant blue CBB R-350 (Amersham Bioscience). For Western blotting, the proteins were electroblotted onto a polyvinylidene difluoride (PVDF) membrane (Daiichi Pure Chemicals Co., Ltd., Ibaraki, Japan). Proteins were reacted with a primary rabbit anti-rat or antimonkey aldehyde oxidase antibody at $0.5 \mu \mathrm{g} / \mathrm{ml}$, a secondary antibody (anti-rabbit fluorescein-linked whole antibody) at a dilution of $1: 600$, and a tertiary antibody (anti-fluorescein alkaline phosphatase conjugate) at a dilution of $1: 2500$. The target proteins on the membrane were detected by an enhanced chemifluorescence (ECF) detection system (Amersham Bioscience). An HMW Calibration Kit and HMV Native Marker Kit (Amersham Bioscience) were used for molecular mass standards.

Structural Analysis of the Purified Enzymes by NanoLC Q TOF/MS The CBB-stained proteins on SDS-PAGE of the purified enzymes were excised and digested with sequencing grade modified trypsin (Promega, Madison, WI, U.S.A.). Briefly, the gel pieces were washed with $50 \%$ acetonitrile $/ 0.1 \mathrm{M}$ ammonium bicarbonate, and then dehydrated with acetonitrile. The proteins in gel pieces were reduced with $10 \mathrm{~mm}$ dithiothreitol (Wako Pure Chemical Industries, Ltd.) and alkylated with $55 \mathrm{~mm}$ iodoacetamide (Sigma). The gel pieces were washed once with $20 \mathrm{~mm}$ ammonium bicarbonate and dehydrated with acetonitrile. The trypsin solution was added to the gel pieces, and the enzyme reaction was allowed to proceed overnight at $37^{\circ} \mathrm{C}$. After digestion, the supernatants were acidified by adding trifluoroacetic acid and immediately subjected to mass spectrometry or stored in a freezer until analysis. Nano-LC/MS/MS experiments were performed on Q-TOF 2 and Ultima API hybrid mass spectrometers (Waters, Milford, MA, U.S.A.) equipped with a nano-electrospray ion source and a CapLC system (Waters). The mass spectrometers were operated in data-directed acquisition mode. For protein identification, all MS/MS spectra were searched using the MASCOT search engine (Matrox Science, Boston, MA, U.S.A.) against the SwissProt data- 
Table 1. Oligonucleotide Primers Used for Amplification of Male Cynomolgus Monkey Aldehyde Oxidase

\begin{tabular}{|c|c|c|}
\hline \multirow[t]{8}{*}{ Degenerate primer } & $1 \mathrm{~F}$ & $5^{\prime}$-tgaaggagaatgatgtggttYWSNccNgt-3' \\
\hline & $1 \mathrm{R}$ & $5^{\prime}$-aggtctgcgttaggRcaYttNSWNa-3' \\
\hline & $2 \mathrm{~F}$ & $5^{\prime}$-gttaaagaccggaatcatHgcNgcNgtNa-3' \\
\hline & $2 \mathrm{R}$ & $5^{\prime}$-ttggcgttgatctcttgYttRtaNggNg-3' \\
\hline & $3 \mathrm{~F}$ & $5^{\prime}$-cgagctgctcttctacgtNaaYNMgN-3' \\
\hline & $3 R$ & $5^{\prime}$-tatgggectgtagccNKKRcaNcKRc-3' \\
\hline & $4 \mathrm{~F}$ & $5^{\prime}$-cgagctgctcttctacgtNaaYggNMgN-3' \\
\hline & $4 \mathrm{R}$ & $5^{\prime}$-tatgggectgtagccNKKRcaNcKRc-3' \\
\hline $\mathrm{mAO} 1 \mathrm{~F}$ & & $5^{\prime}$-gcgtctttcacccaggttataattc- $3^{\prime}$ \\
\hline $\mathrm{mAO} 1 \mathrm{R}$ & & $5^{\prime}$-ttaacatgtcttctcctcgttccag- $3^{\prime}$ \\
\hline 5'GSP1 & & $5^{\prime}$-ggtgcttcctatgccttctactgt-3' \\
\hline 5'GSP2 & & $5^{\prime}$-ctcctccacagccatacttagttc- $3^{\prime}$ \\
\hline 3'GSP1 & & $5^{\prime}$-agcccagcgacaggagaatgcacta- $3^{\prime}$ \\
\hline 3'GSP2 & & $5^{\prime}$-gcaaagcgagctgctaagcaagtgaa-3' \\
\hline
\end{tabular}

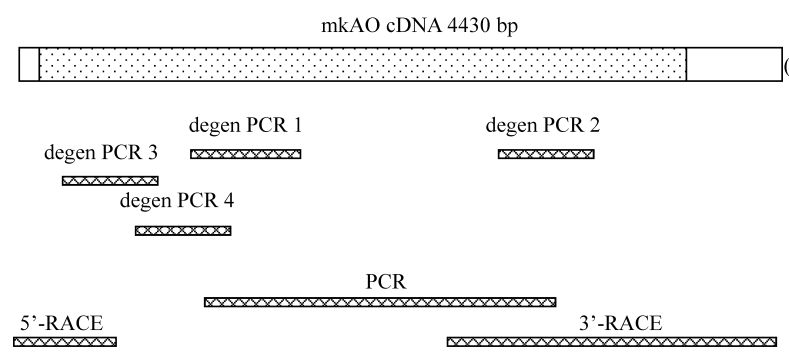

$1 \mathrm{~kb}$

Fig. 1. Structural Organization of Male Cynomolgus Monkey Liver Aldehyde Oxidase cDNA Sequencing

The dots and open boxes indicate the coding region and $5^{\prime}$ - or $3^{\prime}$-untranslated region, respectively. Degenerate PCR was conducted using the four degenerate primers designed by considering the peptide sequences containing the amino acids specific for male cynomolgus monkey liver aldehyde oxidase. Further PCR was performed with primers designed on the degen PCR 1 and the degen PCR 2. In addition, 5'-RACE and $3^{\prime}$-RACE were also carried out. The DNA sequences of those PCR products were assembled to make up the monkey aldehyde oxidase cDNA.

base. A ProteinLynx Global Server (Waters) was used to characterize the specific amino acid sequences of the purified enzymes from male cynomolgus monkey liver.

cDNA Sequences of Male Cynomolgus Monkey Aldehyde Oxidase Four degenerate primers were designed by considering the peptide sequences containing amino acids specific for male cynomolgus monkey liver aldehyde oxidase (Table 1). The structural organization of monkey liver aldehyde oxidase cDNA is shown in Fig. 1. PCR was conducted in a solution of $50 \mu \mathrm{l}$ containing Platinum Taq buffer, $200 \mu \mathrm{M}$ dNTP solution, 2.5 U Platinum Taq DNA polymerase (Invitrogen, Carlsbad, CA, U.S.A.), $2 \mathrm{mM} \mathrm{MgCl}_{2}, 1 \mu \mathrm{M}$ of each primer, and $1 \mu \mathrm{l}$ of the template. PCR amplifications were as follows: initial denaturation at $94^{\circ} \mathrm{C}$ for $5 \mathrm{~min}$, and 35 cycles of $94^{\circ} \mathrm{C}$ for $30 \mathrm{~s}, 60^{\circ} \mathrm{C}$ for $30 \mathrm{~s}, 68^{\circ} \mathrm{C}$ for $30 \mathrm{~s}$, and a final extension at $68^{\circ} \mathrm{C}$ for $10 \mathrm{~min}$. Each product was cloned into the $\mathrm{pCR}-\mathrm{TOPO}$ vector and sequenced.

The resulting sequence was used to derive the unique primer for monkey aldehyde oxidase, and PCR was performed. The reaction was conducted in a solution of $50 \mu \mathrm{l}$ containing Ex-Taq buffer, $200 \mu \mathrm{M}$ dNTP solution, $2.5 \mathrm{U} E x$ Taq polymerase (TaKaRa Bio Inc., Shiga, Japan), $2 \mathrm{~mm}$ $\mathrm{MgCl}_{2}, 1 \mu \mathrm{M}$ of each primer (mAO1 F/R, Table 1$)$, and $1 \mu \mathrm{l}$ of the template. PCR amplifications were as follows: initial denaturation at $94{ }^{\circ} \mathrm{C}$ for $4 \mathrm{~min}$, and 35 cycles of $94{ }^{\circ} \mathrm{C}$ for
$30 \mathrm{~s}, 65^{\circ} \mathrm{C}$ for $30 \mathrm{~s}, 72^{\circ} \mathrm{C}$ for $30 \mathrm{~s}$, and a final extension at $72^{\circ} \mathrm{C}$ for $7 \mathrm{~min}$. The PCR product was cloned into the pCRTOPO vector and sequenced.

5'-RACE was performed using a FirstChoice ${ }^{\mathrm{TM}}$ RLMRACE kit (Ambion, Austin, TX, U.S.A.) according to the manufacturer's protocol. Monkey liver total RNA was reverse transcribed using the random decamers as a primer for reverse transcriptase. The resulting single strand DNA was amplified by PCR using the $5^{\prime}$ Gene-specific primer 1 (5'GSP1, Table 1) and 5'-RACE outer primer. PCR amplifications were as follows: initial denaturation at $94{ }^{\circ} \mathrm{C}$ for $2 \mathrm{~min}$, and (1) 5 cycles of $94^{\circ} \mathrm{C}$ for $30 \mathrm{~s}, 72^{\circ} \mathrm{C}$ for $1 \mathrm{~min}$, (2) 5 cycles of $94^{\circ} \mathrm{C}$ for $30 \mathrm{~s}, 70^{\circ} \mathrm{C}$ for $1 \mathrm{~min}$ and (3) 25 cycles of $94^{\circ} \mathrm{C}$ for $30 \mathrm{~s}, 63^{\circ} \mathrm{C}$ for $30 \mathrm{~s}, 68^{\circ} \mathrm{C}$ for $1 \mathrm{~min}$, and a final extension at $68^{\circ} \mathrm{C}$ for $10 \mathrm{~min}$. The next step of PCR amplification was performed using the $5^{\prime}$-GSP2 (Table 1) and 5'-RACE inner primer. PCR amplifications were as follows: initial denaturation at $94^{\circ} \mathrm{C}$ for $2 \mathrm{~min}$, and (1) 5 cycles of $94^{\circ} \mathrm{C}$ for $30 \mathrm{~s}$, $72^{\circ} \mathrm{C}$ for $1 \mathrm{~min}$, (2) 5 cycles of $94^{\circ} \mathrm{C}$ for $30 \mathrm{~s}, 70^{\circ} \mathrm{C}$ for $1 \mathrm{~min}$ and (3) 25 cycles of $94^{\circ} \mathrm{C}$ for $30 \mathrm{~s}, 65^{\circ} \mathrm{C}$ for $30 \mathrm{~s}, 68^{\circ} \mathrm{C}$ for $1 \mathrm{~min}$, and a final extension at $68^{\circ} \mathrm{C}$ for $10 \mathrm{~min}$. A single product of $600 \mathrm{bp}$ was obtained and sequenced.

$3^{\prime}$-RACE was performed using a GeneRacer ${ }^{\mathrm{TM}}$ kit (Invitrogen) according to the manufacturer's protocol. Monkey liver total RNA was reverse transcribed using the adapter ligated oligo dT as a primer for reverse transcriptase. The resulting single-strand DNA was amplified by PCR using the 3'-GSP1 (Table 1) and Gene Racer 3'-primer. PCR amplifications were as follows: initial denaturation at $94^{\circ} \mathrm{C}$ for $2 \mathrm{~min}$, and (1) 5 cycles of $94^{\circ} \mathrm{C}$ for $30 \mathrm{~s}, 72^{\circ} \mathrm{C}$ for $3 \mathrm{~min}$, (2) 5 cycles at $94^{\circ} \mathrm{C}$ for $30 \mathrm{~s}, 70^{\circ} \mathrm{C}$ for $3 \mathrm{~min}$, and (3) 25 cycles of $94^{\circ} \mathrm{C}$ for $30 \mathrm{~s}, 72^{\circ} \mathrm{C}$ for $3 \mathrm{~min}, 68^{\circ} \mathrm{C}$ for $30 \mathrm{~s}$, and a final extension at $68^{\circ} \mathrm{C}$ for $10 \mathrm{~min}$. The next step of PCR amplification was performed using the $3^{\prime}$-GSP2 (Table 1) and Gene Racer $3^{\prime}$ nested primer. PCR amplifications were as follows: initial denaturation at $94^{\circ} \mathrm{C}$ for $2 \mathrm{~min}$, and 25 cycles of $94^{\circ} \mathrm{C}$ for $30 \mathrm{~s}, 65^{\circ} \mathrm{C}$ for $30 \mathrm{~s}, 68^{\circ} \mathrm{C}$ for $2 \mathrm{~min}$, and a final extension at $68^{\circ} \mathrm{C}$ for $10 \mathrm{~min}$. A single product of $2000 \mathrm{bp}$ was obtained and sequenced.

cDNA Synthesis and Expression of Male Cynomolgus Monkey Aldehyde Oxidase Total RNA was isolated from male cynomolgus monkey liver with TRIzol Reagent (Invitrogen) according to the manufacturer's instructions. The reverse transcription reactions were performed in a total volume of $50 \mu \mathrm{l}$ containing $5 \mu \mathrm{g}$ of total RNA, $250 \mathrm{ng}$ of random hexamer, $1 \times$ first strand buffer, $10 \mathrm{~mm}$ dithiothreitol, 0.5 $\mathrm{mm}$ each of dNTP, $2.5 \mathrm{~mm} \mathrm{MgCl}_{2}$, and $200 \mathrm{U}$ of a reverse transcriptase (Superscript First-Strand Synthesis System, Invitrogen). The mixture was incubated at $42^{\circ} \mathrm{C}$ for $50 \mathrm{~min}$, heated at $70^{\circ} \mathrm{C}$ for $15 \mathrm{~min}$ to denature the reverse transcriptase, and then cooled to $4{ }^{\circ} \mathrm{C}$.

The cDNA obtained in the above process was used as a template for the synthesis of PCR fragments with the expected $4130 \mathrm{bp}$. The forward and reverse primers were $5^{\prime}$ cctggtaccagcgeggacaccacaatgga-3' with an Acc65I restriction site and 5'-tgagtcgacagagtaatggcaaatatca-3' with a SalI restriction site, respectively. The reaction was conducted in a solution of $50 \mu \mathrm{l}$ containing $1 \times$ KOD-Plus-buffer (Toyobo Co., Ltd., Osaka, Japan), $200 \mu \mathrm{M}$ dNTP solution, $2.5 \mathrm{U}$ KODPlus-DNA polymerase (Toyobo), $2 \mathrm{~mm} \mathrm{MgCl}_{2}, 1 \mu \mathrm{M}$ of each primer, and $1 \mu \mathrm{l}(1 \mu \mathrm{g})$ of the template. PCR amplifications 
Table 2. Purification of Aldehyde Oxidase Responsible for $(S)$-Enantiospecific 2-Oxidation of RS-8359 from Male Cynomolgus Monkey Liver Cytosols

\begin{tabular}{lcccc}
\hline \hline Purification step & $\begin{array}{c}\text { Total protein } \\
(\mathrm{mg})\end{array}$ & $\begin{array}{c}\text { Total activity } \\
\text { (units) }\end{array}$ & $\begin{array}{c}\text { Specific activity } \\
\text { (units/mg) }\end{array}$ & $\begin{array}{c}\text { Purification } \\
(\text { fold })\end{array}$ \\
\hline Cytosol & 6189 & 5046 & 0.8153 & 1.00 \\
Heat treatment & 3815 & 3238 & 0.8486 & 1.04 \\
$20-50 \%\left(\mathrm{NH}_{4}\right)_{2} \mathrm{SO}_{4}$ & 1070 & 1214 & 60 & 1.135 \\
Benzamidine Sepharose & 6.859 & 608.5 & 88.72 & 1.39 \\
Mono Q & 0.878 & 84.17 & 95.87 & 109 \\
Hydroxyapatite & 0.229 & 43.04 & 188.3 & 118 \\
\end{tabular}

were as follows: initial denaturation at $94^{\circ} \mathrm{C}$ for $5 \mathrm{~min}$, and 35 cycles of $94^{\circ} \mathrm{C}$ for $30 \mathrm{~s}, 62^{\circ} \mathrm{C}$ for $30 \mathrm{~s}, 68^{\circ} \mathrm{C}$ for $4 \mathrm{~min}$, and a final extension at $68^{\circ} \mathrm{C}$ for $10 \mathrm{~min}$.

The amplified DNA $(20 \mu \mathrm{g})$ was cleaved with Acc65I and SalI (New England BioLabs, Beverly, MA, U.S.A.). The resulting DNA fragment was cloned into the pQE-30 Xa vector (20 $\mu \mathrm{g}$, QIAGEN, Venlo, The Netherlands) using TaKaRa DNA Ligation Kit Ver. 2 (TaKaRa) according to the manufacturer's protocol. The resulting plasmids were transfected into E. coli XL-1 Blue MRF' (TaKaRa), and the insertion of monkey aldehyde oxidase cDNA into the plasmids was checked by agarose gel electrophoresis after digestion with $\mathrm{SacI}$. The DNA sequences of the products were determined by a CEQ 8000 Analysis System (Beckman-Coulter Inc., Fullerton, CA, U.S.A.) and a DTCS Quick Start Kit (Beckman-Coulter) according to the method recommended by the manufacturer.

Cell Cultures The plasmids purified using Wizard Plus Minipreps DNA Purification Systems (Promega) were then transfected into the expression $E$. coli $\mathrm{M} 15$ cells (pREP4, QIAGEN). A single colony was cultured at $37^{\circ} \mathrm{C}$ overnight in $5 \mathrm{ml}$ of LB medium containing $100 \mu \mathrm{g} / \mathrm{ml}$ of ampicillin and $25 \mu \mathrm{g} / \mathrm{ml}$ of kanamycin. To the overnight culture, $500 \mathrm{ml}$ of LB with $100 \mu \mathrm{g} / \mathrm{ml}$ of ampicillin and $25 \mu \mathrm{g} / \mathrm{ml}$ of kanamycin were added and cultured at $37^{\circ} \mathrm{C}$ until the absorbance at $600 \mathrm{~nm}$ reached 0.6. Then, IPTG $(1 \mathrm{~mm})$ was added and growth of the culture was allowed to continue for $72 \mathrm{~h}$ at $22^{\circ} \mathrm{C}$. The cells were collected by centrifugation at $7000 \mathrm{~g}$ for $10 \mathrm{~min}$ at $4{ }^{\circ} \mathrm{C}$. The cells were solubilized with QIAexpressionist (QIAGEN) according to the manufacturer's instructions. The soluble proteins were applied to a HisTrap HP Column (Amersham Biosciences) fully pre-equilibrated with $10 \mathrm{~mm}$ phosphate buffer ( $\mathrm{pH} 7.4)$ containing $20 \mathrm{~mm}$ imidazole and $0.5 \mathrm{M} \mathrm{NaCl}$ (Buffer A). After being washed with $100 \mathrm{~mm}$ imidazole in Buffer $\mathrm{A}$, the objective enzyme was eluted with $250 \mathrm{~mm}$ imidazole in Buffer A. The protease inhibitors were added to the collected cells, and the solubilized proteins were analyzed by SDS-PAGE/Western blot to investigate their effects on the formation of $130 \mathrm{kDa}$ protein was studied. The inhibitors used were chymostatin $(3 \mu \mathrm{g} / \mathrm{ml})$, leupeptin $(3 \mu \mathrm{g} / \mathrm{ml})$, benzamidine $(783 \mu \mathrm{g} / \mathrm{ml}=5 \mathrm{~mm})$, EDTA $(372 \mu \mathrm{g} / \mathrm{ml}=1 \mathrm{~mm})$, and Protease Inhibitor Cocktail Tablet (Roche Diagnostics GmbH, Penzberg, Germany). One cocktail tablet was dissolved in $1.0 \mathrm{ml}$ of distilled water and $50 \mu \mathrm{l}$ of this solution was used.

Genome DNA Analysis of Male Cynomolgus Aldehyde Oxidase Genome DNA was extracted from male cynomolgus monkey liver with DNAzol Reagent (Invitrogen) according to the manufacturer's protocols. Because the nucleotide sequences of intron 28 were needed in order to analyze the target 3340 nucleotide, the forward (5'-aatgtctctggaggttctgtg-

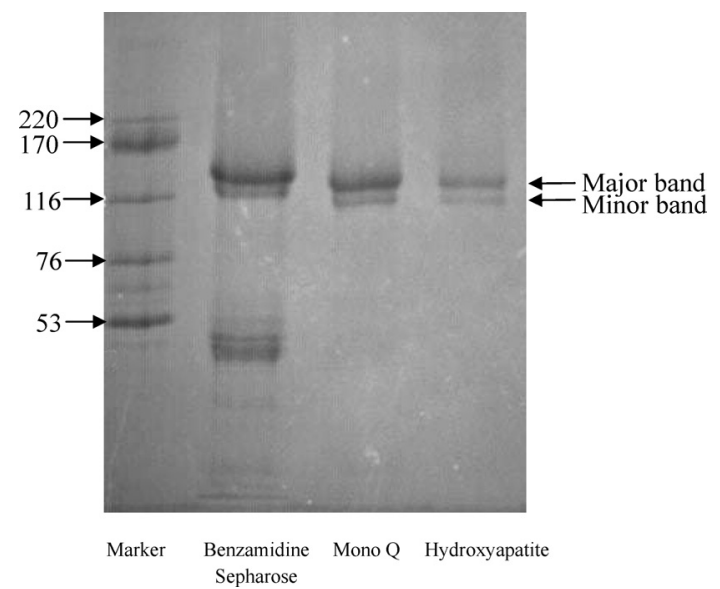

Fig. 2. SDS-PAGE of Purified Aldehyde Oxidase from Male Cynomolgus Monkey Liver Cytosols

$\left.3^{\prime}\right)$ and reverse primer $\left(5^{\prime}\right.$-ttccaagttcctttaggattc- $\left.3^{\prime}\right)$ were designed on exon 28 and 29, respectively. The PCR amplification reaction was performed in a solution of $50 \mu$ l containing template $1 \mu \mathrm{l}, 1 \mu \mathrm{M}$ each of forward primer and reverse primer, $1 \times E x$-Taq buffer, $200 \mu \mathrm{M}$ dNTP mix solution, $2.5 \mathrm{U}$ Ex-Taq

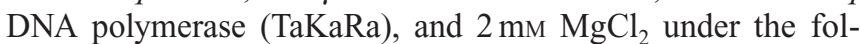
lowing conditions: initial denaturation at $94^{\circ} \mathrm{C}$ for $4 \mathrm{~min}, 35$ cycles of $94^{\circ} \mathrm{C}$ for $30 \mathrm{~s}, 65^{\circ} \mathrm{C}$ for $30 \mathrm{~s}, 72^{\circ} \mathrm{C}$ for $1 \mathrm{~min}$, and a final extension at $72^{\circ} \mathrm{C}$ for $7 \mathrm{~min}$. The amplified DNA was subcloned into pCR-4 TOPO vector in the same manner as mentioned above and the nucleotide sequences of intron 28 were determined. Nucleotide 3340 was analyzed by using the direct sequence primer $\left(5^{\prime}\right.$-acctttgatatcaccttcataca- $\left.3^{\prime}\right)$.

\section{RESULTS}

Purification of Male Cynomolgus Monkey Liver Aldehyde Oxidase Male cynomolgus monkey liver aldehyde oxidase was purified according to the method described previously, ${ }^{10)}$ which included heat treatment, ammonium sulfate fractionation, and column chromatographies of Benzamidine Sepharose 6B, Mono Q anion exchange, and hydroxyapatite. An enzyme preparation with a purification fold of 231 was obtained at a yield of about 1\% (Table 2). SDS-PAGE/CBB staining of the purified samples showed two bands with molecular mass of approximately $150 \mathrm{kDa}$ (major) and $130 \mathrm{kDa}$ (minor), respectively (Fig. 2). Immunoreactive proteins with molecular mass of $250-300 \mathrm{kDa}$ were detected when analyzed by native-PAGE/Western blot (data not shown), suggesting that monkey aldehyde oxidase is a dimeric protein.

Structural Analysis of Purified Enzymes by Nano-LC Q TOF/MS The major $150 \mathrm{kDa}$ and the minor $130 \mathrm{kDa}$ 
proteins on the SDS-PAGE gel were digested by in-gel trypsin, and the resulting tryptic peptide mixtures were analyzed by nano-LC MS/MS. As a result of a Mascot search using MS/MS data against the SwissProt database, both $150 \mathrm{kDa}$ and $130 \mathrm{kDa}$ proteins provided human aldehyde oxidase with top protein hits. The Mascot scores of $150 \mathrm{kDa}$ and
$130 \mathrm{kDa}$ proteins against human aldehyde oxidase were 1033 and 673 , respectively. In addition, the tryptic peptides that did not fit the human aldehyde oxidase sequence were analyzed using ProteinLynx Global SERVER. Fourteen tryptic peptides were characterized as a specific amino acid sequence of monkey liver aldehyde oxidase (data not shown).

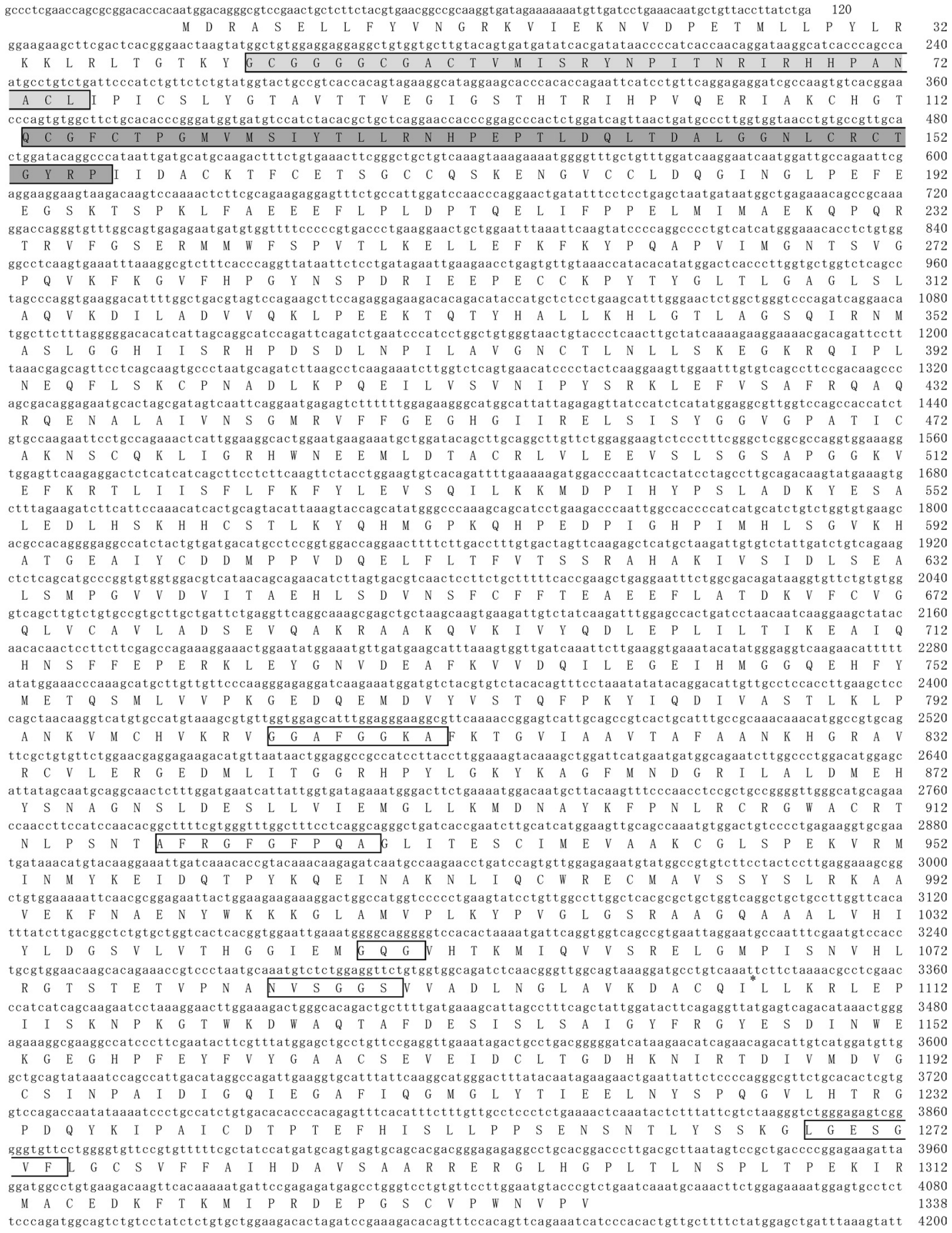

Fig. 3. Sequence of cDNA and Deduced Amino Acids of Male Cynomolgus Monkey Aldehyde Oxidase

The nucleotide sequence of monkey liver aldehyde oxidase cDNA (upper line) was obtained from the overlapping cDNA fragments and is presented with its deduced amino acid sequence (lower line). By reference to the sequences of rat, bovine, and human aldehyde oxidases reported by Wright et al., ${ }^{31)}$ nucleotide residues are numbered in the $5^{\prime}$ to $3^{\prime}$ direction; amino acid residues are numbered from the $N$-terminus to the $C$-terminus, and the two different iron-sulphur centers are boxed (light gray, first $2 \mathrm{Fe}-2 \mathrm{~S}$ redox center; dark gray, second $2 \mathrm{Fe}-2 \mathrm{~S}$ redox center). Similarly, the five molybdopterin cofactor binding sequences are boxed (MoCoI, MoCoII, MoCoIII, MoCoIV, and MoCoV sequences numbered from the $N$-terminus to the $C$-terminus). SNP is indicated with an asterisk. 
After monkey aldehyde oxidase was cloned, nano-LC MS/MS data of purified enzymes from monkey liver were reanalyzed against the sequence of monkey aldehyde oxidase. The sequence coverage of the $150 \mathrm{kDa}$ and $130 \mathrm{kDa}$ proteins against monkey aldehyde oxidase were $44 \%$ and $28 \%$, respectively. The peptides assigned to about 250 amino acids from the $N$-terminus of monkey aldehyde oxidase were observed in $150 \mathrm{kDa}$ protein, but not in $130 \mathrm{kDa}$ protein.

cDNA Cloning of Male Cynomolgus Monkey Aldehyde Oxidase Figure 1 illustrates the PCR amplification strategy used to obtain segments of male cynomolgus monkey liver aldehyde oxidase. We designed the four degenerate primers by considering the peptide sequences containing amino acids specific for monkey liver aldehyde oxidase. The DNA sequence of the four PCR products was assembled to produce the monkey aldehyde oxidase cDNA. The sequences of cDNA and deduced amino acids are shown in Fig. 3. Male cynomolgus monkey aldehyde oxidase is $4430 \mathrm{bp}$ long and consists of a $26 \mathrm{bp} \mathrm{5'}$ untranslated region, a $4014 \mathrm{bp}$ open reading frame coding for a 1338-residue polypeptide, and a $3^{\prime}$ untranslated region of $390 \mathrm{bp}$. The deduced protein had a molecular mass of 147710 which exhibited a high amino acid sequence identity of $96 \%$ with human aldehyde oxidase and $88 \%, 86 \%, 85 \%$, and $83 \%$ with bovine, mouse, rabbit, and rat aldehyde oxidase, respectively. By reference to the sequences of rat, bovine, and human aldehyde oxidases reported by Wright et al., ${ }^{31)}$ the two different iron-sulphur centers and the five molybdopterin cofactor binding sequences were well conserved in male cynomolgus monkey aldehyde oxidase. The nucleotide sequences reported in this paper have been submitted to the DDBJ/EMBL/GenBank Data Libraries under Accession No. AB201545.

Expression and Characterization of Male Cynomolgus Monkey Aldehyde Oxidase After full-length cDNA of male cynomolgus monkey aldehyde oxidase was introduced in the pQE30Xa vector, the cloned cDNA plasmid was transfected to $E$. coli M15 (pREP4) cells for the expression of monkey aldehyde oxidase. The expressed aldehyde oxidases were purified by HisTrap HP column chromatography. A major band with a molecular mass of $150 \mathrm{kDa}$ and a minor band with $130 \mathrm{kDa}$ were detected by SDS-PAGE/Western blot analysis (Fig. 4). The control sample did not exhibit any immunoreactive band.

Using $(S)$-RS-8359 as a substrate, the preparations of expressed male cynomolgus monkey aldehyde oxidase were evaluated for the kinetic parameters of its activity. The similarly expressed Donryu strain rat aldehyde oxidase, that was prepared according to the method described by Itoh et al., ${ }^{23)}$ were used for comparison of activity with monkey enzyme. Eadie-Hofstee plots showed a biphasic profile for monkey

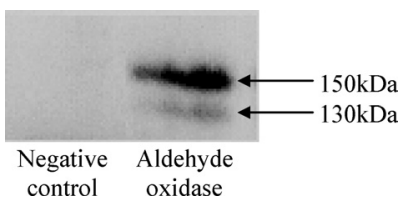

Fig. 4. SDS-PAGE/Western Blot Analysis of Cynomolgus Monkey Aldehyde Oxidase Expressed in E. coli

Aldehyde oxidases were purified from $E$. coli cell lysate in which male cynomolgus monkey aldehyde oxidase was expressed. SDS-PAGE/Western blot of the purified aldehyde oxidases was performed on PhastGel gradient 4-15 in PhastGel SDS Buffer Strips. aldehyde oxidase compared to a monophasic profile for rat aldehyde oxidase (Fig. 5). The kinetic parameters are summarized in Table 3. There was about a 30-fold difference in the $K_{\mathrm{m}}$ values between the high $\left(K_{\mathrm{m}} 2.70 \mu \mathrm{M}\right)$ and low $\left(K_{\mathrm{m}}\right.$ $75.4 \mu \mathrm{M})$ affinity components. In contrast, the $V_{\max }$ values were larger in the low affinity component than were those in the high affinity component. Overall, the high affinity component had about a 6 -fold greater intrinsic clearance $\left(C L_{\text {int }}=\right.$ $\left.V_{\max } / K_{\mathrm{m}}\right)$ than did the low affinity component. Rats demonstrated kinetic parameters closer to those for the low affinity component of monkey than for the high affinity component.

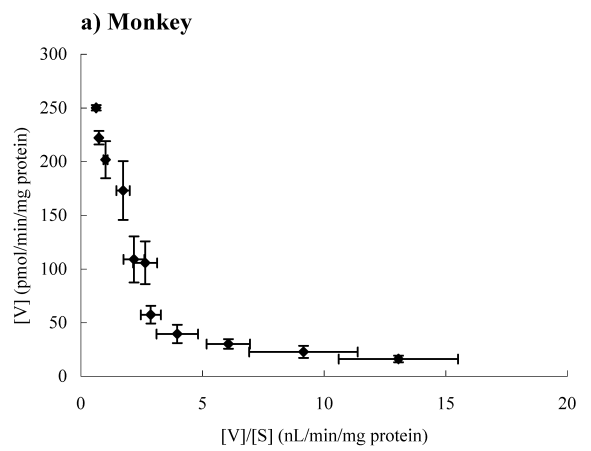

b) Rat

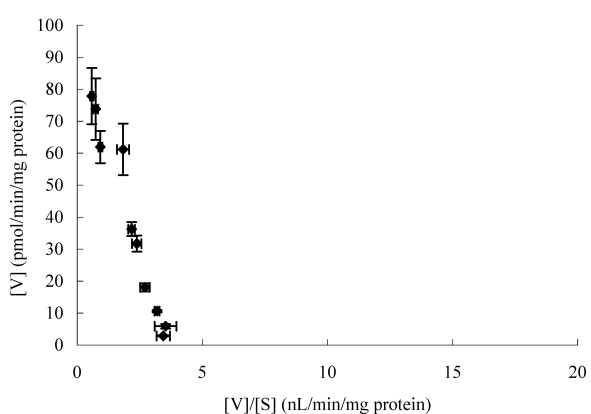

Fig. 5. Representative Eadie-Hofstee Plots for $(S)$-Enantiospecific 2-Oxidation Activity of RS-8359 by Monkey (a) and Rat (b) Aldehyde Oxidase Expressed in E. coli

(S)-RS-8359 (3.1-200 $\mu \mathrm{M})$ was incubated with aldehyde oxidases of monkey and rat expressed in $E$. coli for $30 \mathrm{~min}$ at $37^{\circ} \mathrm{C}$. The enzymes used were purified with a HisTrap HP Column. The 2-oxidative metabolite was measured by HPLC. Data are expressed as the mean \pm S.E. from three determinations.

Table 3. Kinetic Parameters for $(S)$-Enantiospecific 2-Oxidation of RS8359 by Liver Cytosols and Expressed Aldehyde Oxidase

\begin{tabular}{|c|c|c|c|}
\hline Species & $\begin{array}{c}K_{\mathrm{m}} \\
(\mu \mathrm{M})\end{array}$ & $\begin{array}{c}V_{\max } \\
(\mathrm{pmol} / \mathrm{min} / \\
\text { mg protein) }\end{array}$ & $\begin{array}{c}C L_{\text {int }} \\
(\mu \mathrm{l} / \mathrm{min} / \\
\text { mg protein })\end{array}$ \\
\hline \multicolumn{4}{|c|}{ Liver cytosolic enzyme } \\
\hline \multicolumn{4}{|l|}{ Monkey } \\
\hline High affinity & $3.63 \pm 0.34$ & $644 \pm 47.6$ & $179 \pm 17.5$ \\
\hline Low affinity & $61.8 \pm 3.45$ & $3454 \pm 642$ & $56.7 \pm 3.86$ \\
\hline $\operatorname{Rat}^{a)}$ & 90 & 333 & 3.7 \\
\hline \multicolumn{4}{|l|}{ Expressed enzyme } \\
\hline High affinity & $2.70 \pm 0.32$ & $58.2 \pm 7.70$ & $21.5 \pm 4.50$ \\
\hline Low affinity & $75.4 \pm 16.2$ & $287 \pm 5.60$ & $3.80 \pm 1.18$ \\
\hline Rat & $23.8 \pm 5.56$ & $89.8 \pm 14.5$ & $3.89 \pm 0.25$ \\
\hline
\end{tabular}

Kinetic parameters were determined by Eadie-Hofstee plots. The values are the mean \pm S.E. of three independent experiments for the expressed enzyme and three animals for the liver cytosolic enzyme. The expressed enzyme was purified with HisTrap HP Column, but the liver cytosolic enzyme was used without any purification. a) Cited from the previous report. ${ }^{23}$ ) 


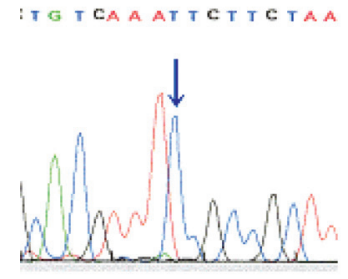

Monkey No. 1

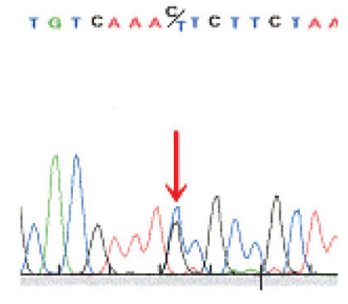

Monkey No. 2

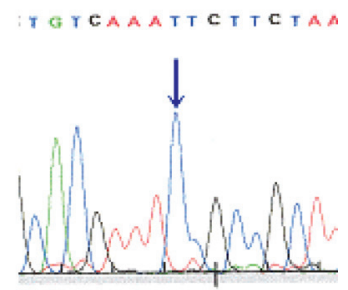

Monkey No. 3

Fig. 6. Direct Sequence of Genomic DNA Including 3340 Base of Three Individual Male Cynomolgus Monkeys

When compared the catalytic activities of cytosol and expressed enzyme, the $K_{\mathrm{m}}$ values were not different from each other. However, the $V_{\max }$ values for the expressed aldehyde oxidase preparations were smaller than were those for the liver cytosolic enzyme.

Genome DNA Analysis of Male Cynomolgus Monkey Aldehyde Oxidase Amino acid residue 1105 was deduced to be Ile from the determined nucleotide sequence $3340 \mathrm{~T}$. In contrast, two corresponding peptides, $\mathrm{D}^{1101} \mathrm{ACQ}{ }^{1} L_{L K}{ }^{1108}$ and $\mathrm{D}^{1101} \mathrm{ACQTLLK}^{1108}$, were observed in nano-LC MS/MS of tryptic digest of the purified enzymes. In order to clarify the sequence variation, the genome DNA of monkey aldehyde oxidase was analyzed. The three liver samples used for the genome DNA analysis were the same ones as those used for the enzyme purification. Two monkeys had homozygous T/T, which codes Ile, at nucleotide position 3340 and one monkey showed heterozygous $\mathrm{C} / \mathrm{T}$, which codes Thr (Fig. 6). There was no difference in aldehyde oxidase activity between the individuals with homozygous $\mathrm{T} / \mathrm{T}$ and heterozygous $\mathrm{C} / \mathrm{T}$ sequence, although a statistical analysis was not conducted because of the very small number.

\section{DISCUSSION}

Species differences in aldehyde oxidase have been well documented for many drugs. ${ }^{4,50-15)}$ Although the order of aldehyde oxidase activity among animal species may vary depending on the substrates, it generally seems to be high in monkeys and humans and low in rats, whereas dogs are deficient of the activity. ${ }^{4,5)}$ This was also the case for the aldehyde oxidase-catalyzed $(S)$-enantiospecific 2-oxidation of RS-8359. ${ }^{20,21)}$ Even though many papers discuss species differences in aldehyde oxidase, little is known about why such a large species difference is present in the enzyme. We set out to characterize monkey aldehyde oxidase using methods of molecular technology as one method of clarifying the mechanism of species differences in aldehyde oxidase.

Male cynomolgus monkey aldehyde oxidases were purified from liver cytosolic fractions. Two bands, a major one with $150 \mathrm{kDa}$ molecular mass and a minor one with $130 \mathrm{kDa}$ molecular mass, were detected by SDS-PAGE/CBB staining. Two bands were also observed by SDS-PAGE/Western blot analysis of the monkey liver cytosol. The minor protein band was detected in human liver cytosol, but not in rat liver cytosol (data not shown). Both protein components were identified as aldehyde oxidase by a Mascot database search of nano-LC Q/TOF MS/MS data. Based on the sequence coverage against monkey aldehyde oxidase, the minor component was presumed to be deficient of $20-30 \mathrm{kDa}$ mass from the
$N$-terminus of the enzyme. Similarly, the minor component was observed in the E. coli expression system of male cynomolgus monkey aldehyde oxidase. Addition of protease inhibitors while preparing monkey liver cytosol and solubilizing the collected $E$. coli cells did not affect the production of $130 \mathrm{kDa}$ protein. The findings suggested that the $130 \mathrm{kDa}$ protein seems to have already been formed by a proteolytic process after being biosynthesized within ribosomes in the liver cells of monkey and human, but not of rat, and also in E. coli cells transfected with monkey aldehyde oxidase cDNA. Whether $130 \mathrm{kDa}$ protein will maintain aldehyde oxidase activity is very important in considering its role. Determining the cleaved site of $150 \mathrm{kDa}$ protein might be helpful for assuming the effect of 20-30 kDa deficiency on enzyme activity, and also the species differences in $130 \mathrm{kDa}$ protein production. A more useful mean would be to construct an expression system of a $130-\mathrm{kDa}$ component and characterize the properties of the expressed enzyme. The problem is a subject that should be verified in the near future. Sugihara et $a l .{ }^{39)}$ reported that monkey aldehyde oxidase consisted of two major $(136,151 \mathrm{kDa})$ and two minor forms $(130,145 \mathrm{kDa})$, and they were not proteolytic cleavage products during preparation. Thus, the existence of isoforms of aldehyde oxidase might be possible in monkey liver. Sugihara et al. also showed a single aldehyde oxidase in liver cytosols of mouse and rat, which is consistent with our results.

The full cDNA of male cynomolgus monkey liver aldehyde oxidase was cloned using four degenerate primers, and then the nucleotide sequences were analyzed. The 1338 amino acid residues were deduced from the determined nucleotide sequences composed of $4430 \mathrm{bp}$. They showed high amino acid identities of over $80 \%$ with those of the other animals, in particular $96 \%$ with human aldehyde oxidase. The high amino acid identities between monkey and human might support their mutual similarities in various enzymological properties including the presence of the $130 \mathrm{kDa}$ minor protein.

Sequence variation at amino acid residue 1105 was observed in male cynomolgus monkey aldehyde oxidase. The peptides that amino acid residue 1105 was Thr or IIe, were determined by nano-LC MS/MS analysis of the purified enzymes. Genome DNA analysis of the three monkeys used for the purification of aldehyde oxidase revealed that nucleotide sequence 3340 was the homozygous $\mathrm{T} / \mathrm{T}$ coding Ile for the two monkeys and the heterozygous $\mathrm{C} / \mathrm{T}$ coding $\mathrm{Thr}$ for the one monkey. The enzymes were purified from the mixed liver cytosols of the three monkeys. Therefore, both Thr and IIe at amino acid residue 1105 were confirmed by nano-LC MS/MS. It seems that the main nucleotide 3340 and corre- 
sponding amino acid 1105 in monkey liver aldehyde oxidase is $\mathrm{T} / \mathrm{T}$ and Ile, respectively. All three individual monkeys used in this study showed a biphasic pattern in Eadie-Hofstee plots and similar kinetic parameters for the $(S)$-enantiospecific 2-oxidation activity of RS-8359, as mentioned below. The results suggest that the nucleotide substitution might not affect the properties of monkey aldehyde oxidase, although a statistical analysis was not performed because of the very small number.

The kinetic parameters were determined for the $(S)$-enantiospecific 2-oxidation activity of RS-8359 with the monkey and rat aldehyde oxidase expressed in E. coli. Eadie-Hofstee plots showed a biphasic pattern for monkey enzyme and a monophasic pattern for rat enzyme. The results suggested that the existence of two forms of aldehyde oxidase in monkey could cause a biphasic pattern. However, there is a possibility that the biphasic phenomenon is produced by two active sites in a single aldehyde oxidase or by some other factors. Further, the $V_{\max }$ values for the expressed monkey aldehyde oxidase are still smaller than are those for the cytosolic enzyme. Because the expressed enzyme is almost pure, whereas cytosol is a complex admixture containing various proteins, the values obtained with the expression system should be larger than those obtained with the cytosolic preparations. The discrepancy should be an interesting subject for elucidation in future studies.

In conclusion, both the major and minor immunoreactive proteins purified from male cynomolgus monkey liver cytosolic fractions were identified to be aldehyde oxidase by a database search of MS data obtained with nano-LC Q/TOF MS. The two protein components were also confirmed in an enzyme preparation expressed in E. coli. They appeared to be products of a single gene, and not proteolytic artifacts created during purification. The expressed and cytosolic aldehyde oxidase of monkey showed a biphasic pattern in Eadie-Hofstee plots of the $(S)$-enantiospecific 2-oxidation activity of RS-8359. The biphasic phenomenon might be caused by the existence of two isoforms, but other mechanisms such as two active sites in a single aldehyde oxidase protein are possible. These issues are now being investigated in this laboratory.

Acknowledgments The authors wish to thank Dr. T. Ikeda, Director of the Drug Metabolism and Pharmacokinetics Research Laboratories, Sankyo Co., Ltd., and Drs. K. Nishimura and Y. Kawahara, Ex-directors of the Research Laboratories, for their kind encouragement.

\section{REFERENCES}

1) Beedham C., Drug Metab. Rev., 16, 119-156 (1985).

2) Beedham C., Prog. Med. Chem., 24, 85-121 (1987).

3) Beedham C., Pharm. World Sci., 19, 255-263 (1997).

4) Beedham C., "Enzyme Systems That Metabolise Drugs and Other Xenobiotics," ed. by Ioannides C., Wiley, London, 2002, pp. 147 187.

5) Kitamura S., Sugihara K., Ohta S., Drug Metab. Pharmacokinet., 21, 83-98 (2006).

6) Kitamura S., Sugihara K., Tatsumi K., Biochem. Mol. Biol. Int., 34, 1197-1203 (1994).

7) Sugihara K., Kitamura S., Tatsumi K., Biochem. Mol. Biol. Int., 40, 535-541 (1996).
8) Prakash C., Kamel A., Gummerus J., Wilner K., Drug Metab. Dispos., 25, 863-872 (1997).

9) Beedham C., Miceli J. J., Obach R. S., J. Clin. Psychophamacol., 23 229-232 (2003).

10) Beedham C., Bruce S. E., Critchley D. J., Al-Tayib Y., Rance D. J., Eur. J. Drug Metab. Pharmacokine., 12, 307-310 (1987).

11) Acheampong A. A., Chien D.-S., Lam S., Vekich S., Breau A., Usansky J., Harcourt D., Munk S. A., Nguyen H., Garst M., Tang-Liu D., Xenobiotica, 26, 1035-1055 (1996).

12) Chaudhary I., DeMario W., Kantrowitz J., Pharm. Res., 11, 319 (1994).

13) Jordan C. G. M., Rashidi M. R., Laljee H., Clarke S. E., Brown J. E., Beedham C., J. Pharm. Pharmacol., 51, 411-418 (1995).

14) Kitamura S., Nakatani K., Sugihara K., Ohta S., Com. Biochem. Phys. $C, \mathbf{1 2 2}, 331-336$ (1999).

15) Rashidi M. R., Smith J. A., Clarke S. E., Beedham C., Drug Metab. Dispos., 25, 805-813 (1997).

16) Sugihara K., Kitamura S., Tatsumi K., Biochem. Mol. Biol. Int., 37, $861-869$ (1995)

17) Kitamura S., Nakatani K., Ohashi K., Sugihara K., Hosokawa R., Akagawa Y., Ohta S., Biol. Pharm. Bull., 24, 856-859 (2001).

18) Beedham C., "Metabolism of Xenobiotics," ed. by Gorrod J. W., Oeschlager H., Caldwell J., Taylor \& Francis, London, 1998, pp. 5158.

19) Stanulovic M., Chaykin S., Arch. Biochem. Biophys., 145, 27-34 (1971).

20) Takasaki W., Yamamura M., Nozaki A., Nitanai T., Sasahara K., Itoh K., Tanaka Y., Chirality, 17, 135-141 (2005).

21) Itoh K., Yamamura M., Takasaki W., Sasaki T., Masubuchi A., Tanaka Y., Biopharm. Drug Dispos., 27, 133-139 (2006).

22) Sasaki T., Masubuchi A., Yamamura M., Watanabe N., Hiratsuka M., Mizugaki M., Itoh K., Tanaka Y., Biopharm. Drug Dispos., 27, 247255 (2006).

23) Itoh K., Masubuchi A., Sasaki T., Adachi M., Watanabe N., Nagata K., Yamazoe Y., Hiratsuka M., Mizugaki M., Tanaka Y., Drug Metab. Dispos., 35, 734-739 (2007).

24) Yokoyama T., Karube T., Iwata N., J. Pharm. Pharmacol., 41, 32-36 (1989).

25) Kumagae Y., Matsui Y., Iwata N., Jpn. J. Pharmacol., 55, 121-128 (1991).

26) Miura H., Naoi M., Nakahara D., Ohta T., Nagatsu T., J. Neural. Transm., 94, 175-187 (1993).

27) Puchler K., Schaffler K., Plenker A., Int. Clin. Psychopharm., 12, S17-S23 (1997).

28) Plenker A., Puchler K., Volz H. P., Int. Clin. Psychopharm., 12, S25S29 (1997).

29) Kurosaki M., Demontis S., Barzago M. M., Garattini E., Terao M., Biochem. J., 341, 71-80 (1999).

30) Terao M., Kurosaki M., Saltini G., Demontis S., Marini M., Salmona M., Garattini E., J. Biol. Chem., 275, 30690-30700 (2000).

31) Wright R. M., Clayton D. A., Riley M. G., McManaman J. L., Repine J. E., J. Biol. Chem., 274, 3878-3886 (1999).

32) Huang D. Y., Furukawa A., Ichikawa Y., Arch. Biochem. Biophys., 364, $264-272$ (1999).

33) Calzi M. L., Raviolo C., Ghibaudi E., Gioia L. D., Salmona M., Cazzaniga G., Kurosaki M., Terao M., Garattini E., J. Biol. Chem., 270, 31037-31045 (1995).

34) Wright R. M., Vaitaitis G. M., Wilson C. M., Repine T. B., Terada L. S., Repine J. E., Proc. Natl. Acad. Sci. U.S.A., 90, 10690-10694 (1993).

35) Berger R., Mezey E., Clancy K. P., Harta G., Wright R. M., Repine J. E., Brown R. H., Brownstein M., Patterson D., Somat. Cell Molec. Genet., 21, 121-131 (1995).

36) Turner N. A., Doyle W. A., Ventom A. M., Bray R. C., Eur. J. Biochem., 232, 646-657 (1995).

37) Terao M., Kurosaki M., Demontis S., Zanotta S., Farattini E., Biochem. J., 332, 383-393 (1998).

38) Demontis S., Kurosaki M., Saccone S., Motta S., Garattini E., Terao M., Biochem. Biophys. Acta, 1489, 207-222 (1999).

39) Sugihara K., Katsuma Y., Kitamura S., Ohta S., Fujitani M., Shintani H., Com. Biochem. Physiol. C, 126, 53-60 (2000). 